because of the risk of descent far from help and in the second because of the small hope of recovering the instruments.

\section{New British Birds}

THE addition of six birds new to the British list, and the alteration in nomenclature of another, has been agreed to by the council of the British Ornitho. logists' Union (Ibis., July 1934); and no less than three of the new types are birds from South Uist, Outer Hebrides, where they were distinguished and described by Col. Meinertzhagen. The newly added species are: the Hebridean twite (Aianthis flavirostris bensonorum) which is darker and not so red as the common twite (Linota $(A)$.$f . flavirostris)$ and with blacker centres to its feathers, the underparts being similar to the mainland birds; the Hebridean stonechat (Saxicola torquata theresoe), the female of which is not so red and darker above and below than the common stonechat (Saxicola $t$. hibernas), the black bases of her throat-feathers being more conspicuous-the male is slightly darker above, especially on the forehead, but with the underparts similar; the Hebridean hedge-sparrow (Prunella modularis hebridium) with general darker plumage than the common hedge-sparrow (Accentor modularis occidentalis), the flanks being more heavily marked and streaked, the upper parts richer and more distinctly marked and the grey on the throat darker. The types of these three birds were obtained from South Uist, the latter bird being the least common. The other additions are the Scandinavian jackdaw (Corvus monedula monedula) from a specimen obtained at Lowestoft and described as a migrant to the east coast of England; the arctic ringed-plover (Charadrius hiaticula tundrae), a well-established race distinguished from the common bird (Ch.h.h.) by its smaller size and darker colour, nesting in Lapland, Arctic Russia and Siberia, a specimen in the British Museum being from Poole Harbour, Sussex; and the bridled or lesser sooty tern (Sterna ancethetus) of the West Pacific and Indian Oceans, which has been obtained from Dungeness and a Thames lightship. The British song thrush has been altered from Turdus philomelus clarkei to Turdus ericetorum ericetorum, and correspondingly, the continental song thrush to T.e. planiceps, and the Hebridean song thrush to $T$. e. hebridensis.

\section{High Wind Speed at Mount Washington}

IN the Engineering News-Record of May 10, 1934, there is an article about the alleged wind speed of 231 miles an hour said to have been attained at the meteorological observatory of Harvard University on Mount Washington, New Hampshire, on April 12, 1934. Most meteorologists-at least European ones-probably paid little attention to the reports of this wind that appeared in the newspapers soon after that date, on the grounds that such a wind could not have been measured even if it actually occurred, but Dr. C. F. Brooks, professor of meteorology at Harvard, is quoted as stating that the speed in question was recorded by an anemometer of the cup pattern, similar in principle to the well known Robinson anemometer, and is probably correct to within about ten miles an hour. It appears that the design of the instrument was roughly copied from an experimental anemometer seen at Bergen in 1931, modifications being introduced to meet the difficult conditions sometimes experienced at Mount Washington, in very windy weather, that may result in massive ice formations due to rime. Electrical heating of the anemometer of a very powerful kind had to be introduced, and hot air was made to pass through the six cups, which were fitted closely round a copper disc placed over an electric stove, and were driven in the normal manner by the pressure of the wind. The instrument was tested in a wind tunnel at the Bureau of Standards up to a speed of 150 miles an hour, and as the calibration curve became nearly straight towards the maximum speeds it seemed justifiable to extrapolate to 231 miles an hour, with the probability of obtaining a figure not significantly different from the true figure. The speed in question was the average, while three contacts were made, each representing the passage of $1 / 30$ mile of air past the cups and was therefore for a gust.

\section{Forestry in Trinidad and Tobago}

THE annual report of the Forest Department of Trinidad and Tobago, 1933, has recently been published (Govt. Printer, Port of Spain, Trinidad, 1934). The satisfactory lines upon which the Department has been working, with the active support of the Government, is evident. The Government has obviously placed implicit trust in its Conservator, Capt. R. C. Marshall, who, after eleven years in the colony, is now taking up the post of conservator of forests in the Gold Coast. The acting conservator, the writer of the present report, seizes the opportunity of taking stock, in an introduction, of the progress made by the Department during Capt. Marshall's tenure of the post. This review covers all the branches of forest activity and is well worth reading. Progress in sylviculture has been considerable, but there are problems connected with the cedar which have yet to be solved. Most of the Colonial services are as yet so backward in the working plans branch of forestry that it is of interest to read that outline working plans or working schemes have been prepared for an area of approximately 90,000 acres of reserves. Under finance, the acting conservator shows that the surplus of revenue over expenditure for the eleven-year period, exclusive of free timber supplied to the P.W. Department (an iniquitous practice since, as a former Governor-General of India expressed it, Government is in effect taking free from the State forests materials for which the public has to pay), amounted to $£ 5 \mathrm{I}, 017$; revenue fluctuated from $£ 25,054$ in 1927 to $£ 8,466$ in 1931 . The writer continues : "The Forest Department has repeatedly emphasized in its Annual Reports that the higher revenues are liable to be unstable, much of them being due to the clearing activities of Oil Companies, and that the Department's endeavours in this direction are primarily concentrated on obtaining a stable 
revenue by supplying the Colony's ordinary woodconsuming industries with local timber. Some of this high revenue is in reality trust capital and strictly. speaking ought to be treated as such."

\section{Nature Protection in Poland}

DURING its spring session, the Parliament of Poland discussed and passed a new law for the protection of Nature, a comprehensive measure covering many objects (Kwartalny Biuletyn Informacyjny, 4 ; 1934). The threat of the erection of tourist mountain railways on the Polish, as well as on the Czechoslovakian, side of the Tatras has aroused much concern and opposition, for it would interfere with the object, which seemed to be on the point of fulfilment, of creating a grand Tatras National Park jointly cared for by Poland and Czechoslovakia. In the eastern Carpathians, there has been created by the Metropolitan of the Greek-Catholic Church, a new Nature reserve, interesting because it protects a fine forest of Cembro pines (Pinus Cembra) growing upon the summit of Mount Jajko. Indeed the protection of ancient trees is one of the features of the Polish scheme, and one of the most remarkable grows in the village of Harbutowice in the west Carpathians - the oldest yew in the country, having a circumference of 2.80 metres. An excellent step has been taken in enlisting the co-operation of the school authorities in the Cracow and other districts; and with the object of familiarising school teachers with the objects and methods of Nature protection, special conferences have been held at which discussions have taken place on the feeding of birds in winter, and on the plants specially protected in the school districts. Another step, which might well be copied in Great Britain, is the agreement come to with the Polish radio authorities arranging that talks will be broadcast once a month on different aspects of the protection of Nature.

\section{Activities of the Post Office}

THE last annual report of the Post Office was issued nearly twenty years ago. Since then, there have been many radical changes and important developments in the work of this Government department which are not yet well known. We therefore welcome "The Post Office, 1934" (London : G.P.O. 1s.) which has just been published. In the preface the Postmaster-General reviews some of the developments, and he may indeed be proud of his department, which has kept well abreast of all the latest scientific advances. Owing to the competition of telephony, the traffic handled by the telegraph service shows a considerable falling off, but the rapid and revolutionary changes introduced are checking this decline. The teleprinter is now the standard machine in use in Britain; Morse signalling is rarely used. A motor-cycle service has quickened delivery, and incoming liners are met by telegraph representatives. As an experiment, boy messengers are attending a few of the main railway stations to accept telegrams from outgoing passengers. Up to twenty years ago, the telegraph was the only means of communication with foreign countries; now a telephone subscriber in Great Britain can communicate with 95 per cent of the telephone subscribers of the world. Wonderful progress has been made with radio services. For broadcasting, unfortunately, the wave-length position in Europe is very difficult owing to the fact that there are far more broadcasting stations than there are wavelengths available for their use. Some countries were not satisfied with the allocation of wave-lengths made at the Lucerne Conference and are using waves contrary to the Lucerne plan.

\section{Electricity Development in France}

The aim of electrical engineers in France is to create a huge network of high-voltage transmission lines which will connect the generating stations with the great centres of consumption. The systems of transmission are being standardised. For the hightension lines, 220 and 150 kilovolts are being used, and secondary pressures of 90 and 60 are employed. This compares with the 132 kilovolts used in the British Grid. A report issued by the Department of Overseas Trade on "Economic Conditions in France" by Sir Robert Cahill (London: H.M. Stationery Office, $7 s$. net) gives much instructive information on this subject. It is stated that the production and distribution of electricity in France provide employment for 150,000 workers. The yearly output has been estimated at about one twentieth of the total world output. There are 1,200 companies producing or distributing electricity, and the productive capacity of the stations increased very rapidly before the commercial depression and is still increasing. The output of the great thermal stations of the coalmining, metallurgical and industrial areas, north and east of Paris, and in the vicinity of Lyons, will form in a few years' time part of a comprehensive electrical supply system, so that any temporary breakdown in the supply from one station can be made good from the others. The output of the thermal is double that of the hydro-electric stations. There still remains about 60 per cent of the maximum possible water-power not utilised. The Rhine development scheme includes the erection of eight large power stations at intervals along the river. The first, which is already in operation, is at Kembs, about ten miles below Basle, and is equipped to produce nearly 200,000 kilowatts. The combined power of the eight stations will be 650,000 kilowatts. Various schemes have been proposed and stations built for utilising tidal power on the coast of Brittany, but so far none of them seems to have been commercially successful.

\section{Social Insurance}

THE importance of demographic considerations in relation to social problems are stressed by Prof. J. P. Dalton in a pamphlet on "Social Insurance" recently published by the University of the Witwatersrand Press, Johannesburg. The author claims that the demographic consequences of social processes are in the long run of paramount importance, though they are usually ignored or ill-understood. He argues 